\title{
KINERJA LEMBAGA KEUANGAN MIKRO DAN PERILAKU MASYARAKAT PEDESAAN *)
}

\author{
Sumantoro M artowijoyo ${ }^{* *}$ )
}

\begin{abstract}
Setelah disuguhi banyak topik moneter dengan teknik-teknik analisis canggih ekonometrika tingkat pascasarjana, tulisan ini mengajak pembaca untuk turun kedunia nyata tempat sebagian besar saudara kita sebangsa hidup. D i era pengentasan kemiskinan ini, Indonesia telah menjadi laboratorium bagi penelitian di bidang Lembaga Keuangan M ikro(LKM ), karena memiliki berbagai jenis sejak lama. Di luar BRI U nit yang meru pakan kisah sukses tingkat dunia, ada Badan K redit Desa yang didirikan di zaman Belanda, Badan Kredit Kecamatan di Jawa Tengah, di samping berkembangnya kelompok-kelompok swadaya masyarakat sebagai bentuk lembaga keuangan yang paling sederhana di tingkat "akar rumput".
\end{abstract}

D i sini dibahas beberapa faktor yang menggambarkan perilaku masyarakat perdesaan yang mempengaruhi kinerja lembaga keuangan mikro, misal nya: jam kerja, jarak rata-rata antara lokasi LKM kelokasi nasabah, waktu pemrosesan kredit, tingkat penghasilan nasabah, suku bungatabungan dan suku bunga pinjaman. D ari hasil analisis dapat diungkapkan, bahwa faktor yang paling mempen garuhi kinerja adalah jarak kelokasi nasabah dan selang waktu pemrosesan kredit. Tergambar pula masi h lugu dan mandirinyasifat pengusahamikro perdesaan nasabah LKM dibanding pengusaha kongl omerat nasabah bank umum: apabila kenaikan pendapatan pengusaha mikro perdesaan dipakai untukmenambah tabungan dan melunasi tunggakan, tidak demikian halnya pengu saha konglomerat, karena sebagian justru sengaja memacetkan kreditnya.

U kuran "kinerja" sendiri jauh berbeda dengan kriteriaCAM EL yangtidakakan mudahtercerna oleh kesahajaan lembaga-lembaga tersebut, dan kiranya akan menjadi topik pembicaraan tersendiri.

\footnotetext{
*) Bagian dari tulisan yang sedang dalam proses, kenangan dan salam perpisahan penulis kepada Urusan Kredit, Bank Indonesia

**) Sumantoro Martowijoyo : Peneliti pada Tim Penyiapan Pusat Pendidikan dan Riset, USDM, Bank Indonesia
} 


\section{Latar Belakang}

D

engan disepakatinya ikrar dalam M icrocredit Summit di Washington DC Amerika Serikat pada tahun 1997 untuk membebaskan 100 juta penduduk dunia dari kemiskinan, pencarian model lembaga keuangan mikro ${ }^{1}$ yang tepat untuk melayani rakyat miskin dilakukan di mana-mana. Setelah dua dasawarsa diwarnai kreditkredit murah bersubsidi yang sebagian tidak jatuh ke tangan kelompok sasaran dan mengakibatkan merosotnya kinerja serta moralitas lembaga keuangan pelaksananya, para pakar merekomendasikan prinsip keswadayaan dan kesehatan (viability) dari programprogram pengentasan kemiskinan. M odel Grameen Bank Bangladesh direplikasikan di manamana, dan lembaga-lembaga swadaya masyarakat (LSM) bergiat membina keswadayaan masyarakat melalui kelompok-kelompok swadaya masyarakat (KSM). Di luar perhatian para penentu kebijakan kita, Indonesia sebetulnya sudah lebih maju dalam penciptaan lembaga keuangan mikro sejak zaman Belanda, di samping BRI Unit yang merupakan kisah sukses dunia. Dalam pengembangan KSM Bank Indonesia ikut berkiprah melalui Pengembangan Hubungan Bank dengan Kelompok Swadaya Masyarakat (PHBK) yang gagasannya berasal dari APRACA (A sia Pacific Rural and A gricultural Credit A ssociation), dan dalam pengembangan LKM melalui Proyek Kredit Mikro yang didanai bersama A sian D evelopment Bank.

\section{Lembaga Keuangan Mikro di Indonesia}

Selain lembaga yang formal seperti BRI Unit dan BPR yang secara hukum diakui sebagai lembaga keuangan formal (bank), terdapat banyak LKM yang semiformal maupun informal di Indonesia. Tiga lembaga yang dipilih adalah yang efektif beroperasi di tingkat "akar rumput" dan menerapkan prinsip suku bunga pasar yang terbukti lestari, tanpa melihat status hukumnya.

\section{Kelompok Swadaya Masyarakat}

Di Indonesia, kegiatan yang dilakukan secara kelompok sudah merupakan budaya masyarakat yang berazaskan paguyuban. Kegiatan arisan sudah tumbuh menjamur diperdesaan dan perkotaan dan jumlahnya mungkin melebihi satu juta.

A pabila kebutuhan akan uang tersebut makin terasa dan jumlah yang diperoleh dari arisan terlalu kecil, timbullah gagasan untuk menambah jumlah dan jenis uang setoran menjadi simpanan pokok, simpanan wajib, dan simpanan sukarela. Dengan begitu,

1 banyak pula yang menyebutnya rural financial institutions (RFI) atau lembaga keuangan pedesaan (LKP), tapi untuk Indonesia karena lokasinya banyak pula di perkotaan maka dipilih istilah yang dikenal sejak Summit ini Istilah "mikro" selain menunjuk skala yang lebih kecil dari yang kecil, konotasinya terkait dengan kemiskinan 
perkumpulan arisan telah berubah menjadi koperasi kredit (credit union), di mana untuk peminjaman uang ditarik pula semacam “jasa” yang dipotongkan dari jumlah pinjaman. Perkumpulan semacam ini secara tidak sadar sudah berfungsi sebagai lembaga keuangan perdesaan: menghimpun dana dan memberikan kredit kepada anggota, memungut bunga berupa “jasa”, serta di akhir tahun membagikan dividen bagi para pemegang saham.

Berkembangnya KSM di Indonesiatidak lepas dari berkembangnyalembaga swadaya masyarakat (LSM) dari tahun 1960-an sampai awal 1990-an yang jumlahnya diperkirakan antara 1000-2000 buah (Saidi, 1995). Seperti halnya di Filipina, banyak LSM yang lahir dan tumbuh untuk dapat "menangkap" bantuan dari badan atau LSM internasional.

\section{Badan Kredit Desa}

Badan Kredit Desa (BKD) terdiri dari lumbung desa yang didirikan tahun 1897 dan bank desa yang didirikan sekitar tahun 1904 (P. Suharto, 1988) dan keduanya dikukuhkan dengan Staatsblad nomor 357 tahun 1929. Lumbung desa mengumpulkan padi untuk diberikan sebagai pinjaman berupa padi kepada petani di saat mereka membutuhkan. Sedangkan bank desa menghimpun tabungan berupa uang dan memberikan kredit berupa uang. Selama zaman Belanda sistem BKD telah berfungsi dengan baik sebagai lembaga keuangan bagi rakyat perdesaan, berguguran di zaman pendudukan Jepang dan Perang Kemerdekaan, kemudian mulai tumbuh kembali sesudah kemerdekaan.

Sebagai bank sekunder dalam pembinaan BRI, organisasi dan pengelolaan BKD dipertahankan tetap seperti konsep semula yaitu Komisi BKD terdiri dari kepala desa sebagai ketua komisi (Komisi I) dan 2orang pemuka masyarakat atau aparat desa sebagai Komisi II dan III. Pembukuan dilakukan oleh Juru Tata Usaha (JTU) yang bekerja untuk 6BKD secara bergilir (BKD umumnya buka sekali seminggu pada hari atau hari pasaran tertentu). Pengawasan terhadap BKD dilakukan secara langsung oleh Mantri BKD yang mewilayahi satu kemantren yang terdiri dari 18BKD.

Sistem kredit BKD sederhana, terutamaterdiri dari kredit pasaran dan mingguan yang berjangka waktu 12 pasar $^{2}$ atau 12 minggu dengan pembayaran angsuran pokok maupun bunga dengan jumlah yang tetap. Jumlah kredit yang dapat diberikan sampai dengan $\mathrm{Rp}$ 400.000 tanpa agunan, semata-mata berdasarkan penilaian kelayakan nasabah oleh Komisi I.

Dengan berlakunya Undang-undang Perbankan No.7 tahun 1992 yang mencabut berlakunya Staatsblad no. 357 tahun 1929, pengawasan terhadap BKD sebetulnya ada di tangan Bank Indonesia (BI). A kan tetapi mengingat banyak faktor, BI sendiri menyetujui BRI meneruskan tugas pengawasannya terhadap BKD dengan bantuan keuangan dari BI.

2. Satu pasar=5 hari (kalender Jawa), kredit pasaran diberikan oleh BKD yang bukanya setiap hari pasaran tertentu 
Lepas dari suara yang mendiskreditkan BKD, keberadaannya dibutuhkan oleh rakyat dan telah membuktikan kel estarian dan kemandiriannya dalam arti tidak pernah menerima dana maupun subsidi bunga dari pemerintah. Di tengah maraknya kredit Bimas, misal nya, lumbung desa tetap menjadi sumber kredit bagi rakyat kecil untuk konsumsi sehari-hari (Dibyo Prabowo, 1981). Sebagai LKM, BKD mampu menjangkau masyarakat paling miskin di pedesaan, tercermin dari paling rendahnya jumlah kredit rata-rata BKD dibanding beberapa lembaga keuangan mikro yang terkenal di dunia, yaitu sebesar USD 38 di tahun 1993 (Christen, 1995,p.26). Jumlah BKD di Jawa dan Madura tercatat 5345 terdiri dari 4806 yang aktif dan 539 yang tidak aktif (BRI, 1998).

\section{Badan Kredit Kecamatan}

Badan Kredit Kecamatan (BKK) adalah lembaga keuangan yang beroperasi di tingkat kecamatan yang didirikan oleh Pemerintah Daerah Tingkat I Jawa Tengah di awal tahun 1970an dengan status sebagai suatu proyek, dan kemudian dengan Peraturan Daerah (Perda) No. 11 tahun 1981 dikukuhkan menjadi badan usaha milik daerah.

BKK didirikan dengan tujuan: (1) mendekatkan modal pada masyarakat pengusaha miskin di perdesaan dengan caramudah, murah dan mengarah, (2) menciptakan pemerataan kesempatan berusaha di pedesaan, dan (3) mendidik masyarakat pedesaan untuk gemar menabung (BP-BKK,1994). Prosedur permohonan kredit kepada BKK cukup sederhana dan untuk jumlah kredit sampai dengan Rp 500.000 tidak diperlukan agunan selain rekomendasi kepala desa. Selang waktu antara saat pengajuan permohonan dengan realisasi kredit untuk nasabah baru paling lama seminggu, sedangkan untuk nasabah ulangan yang lancar pencairan kredit dapat dilakukan pada hari yang sama.

Jenis kredit BKK sama dengan BKD, yaitu kebanyakan kredit pasaran, mingguan, bulanan ( 3 bulan), dan musiman (6bulan). Sama dengan BKD jumlah angsuran sama setiap pembayaran, hanya menuruti peraturan BPR, dibukukan terpisah sebagai angsuran pokok dan bunga.

Manajemen BKK terdiri dari Pimpinan, Pemegang Kas dan Pemegang Buku. Kinerja manajemen BKK dipantau oleh Camat sebagai penanggung jawab BKK di wilayahnya. Berdasarkan Perda no.11 tahun 1981 Bank Pembangunan Daerah (BPD) Jawa Tengah ditugasi sebagai pembina dan pengawas teknisBKK. BKK diharuskan menyimpan kelebihan alat likuidnya di BPD, di pihak lain apabila BKK kekurangan modal kerja BPD akan memberikan pinjaman likuiditas.

Jumlah BKK di seluruh JawaTengah 510, 202 di antaranya sudah berstatus BPR, ratarata peminjam per unit 978 orang, jumlah pinjaman rata-rata per unit Rp 96 juta dan per nasabah Rp 132.584 (DAI, 1993) 


\section{Metodologi Penelitian}

Penelitian ini dilakukan di lapangan terhadap 105 lembaga keuangan mikro (LKM) di Jawa Tengah, yang merupakan $34 \%$ dari populasi, untuk masing-masing jenis LKM ( $K S M, B K D, B K K$ ) diambil proporsional berdasarkan jumlah populasinya masing-masing secara purposif, beserta masing-masing 3 nasabah per LKM yang diambil secara acak. Analisis data primer dilakukan dengan teknik statistik nonparametrik, pertama dengan uji Kruskal-Wallis untuk beda populasi dan uji Kendall untuk kesesuaian (concordance) pemeringkatan faktor-faktor kinerja, kemudiaan untuk hubungan antarfaktor kinerja dengan korelasi jenjang Spearman ${ }^{3}$. Keuntungan penggunaan statistik nonparametrik adal ah tidak perlu dibuktikannyakenormalan distribusi data (yang merupakan prasyarat bagi sahihnya penggunaan statistik parametrik) dan dapat diterapkannya pada sampel kecil atau data kualitatif (Siegel, 1997).

\section{Faktor-faktor yang mempengaruhi Kinerja LKM}

Terdapat beberapa faktor atau variabel yang secara rasional dianggap mempengaruhi kinerja, seperti: umur LKM, jam kerja, jarak rata-rata ke lokasi nasabah (JARAK), selang waktu pemrosesan kredit (SELANG), penghasilan rata-rata nasabah (RAYNAS), suku bunga tabungan (ITAB), dan suku bunga pinjaman (IPIN).

Mengenai kriteria kinerja, dari pengkajian terhadap falsafah dan hakekat LKM serta pendapat para praktisi keuangan perdesaan, penulis mengajukan beberapa faktor penentu kinerja LKM, yaitu tingkat akseskepada penabung (AKPEN), tingkat akseskepada peminjam (AKPEM), persentase jumlah penunggak (PERPUNG), efisiensi (biaya usaha per rupiah kredit, BIRUP) dan laba per rupiah kredit (LARAP). AKPEN dan AKPEM adalah masingmasing jumlah penabung dan peminjam dibagi jumlah penduduk di wilayah kerja LKM. PERPUNG adalah persentasejumlah penunggak (debitur kreditmacet) dari jumlah peminjam, BIRUP dihitung dari jumlah biaya operasional dibagi dengan saldo pinjaman, sedangkan LARA P merupakan laba bersi sebelum pajak dibagi saldo pinjaman. Kegunaan kriteria ini akan dapat dipahami setelah selesai membaca hasil analisis di belakang.

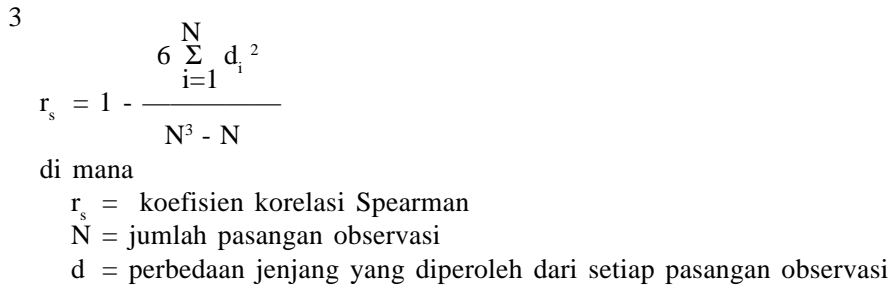




\section{Hasil Analisis}

Uji Kruskal-W allis menghasilkan nilai chi-kuadrat yang sangat signifikan, demikian pula uji Kendall menghasilkan nilai W yang sangat signifikan, membuktikan bahwa angka rata-ratayang dianal isis memang berasal dari tiga populasi yang berbedadan pemeringkatan semua faktor kinerja dilakukan secara konsisten.

Dari hasil analisis korelasi peringkat Spearman antara variabel nonkinerja dengan faktor penentu kinerja terdapat beberapa temuan yang berhubungan dengan perilaku nasabah.

Tabel 1.

Korelasi antara Jarak, Selang dan Sukubunga Pinjaman terhadap Faktor Kinerja

\begin{tabular}{llllll}
\hline & AKPEN & AKPEM & PERPUNG & BIRUP & LARP \\
\hline JARAK & $-.4959(.000)$ & $-.4816(.000)$ & $.3981(.000)$ & $.2292(.019)$ & $-.3406(.000)$ \\
SELANG & $x x x x x x$ & $-.1325(.178)$ & $.076(.474)$ & $.1183(.229)$ & $-.2864(.003)$ \\
\multirow{2}{*}{ IPIN } & $x x x x x x x$ & $-.2674(.006)$ & $.2073(.109)$ & $x x x x x x x$ & $.0276(.780)$ \\
\hline
\end{tabular}

1. Faktor yang berpengaruh pal ing besar terhadap faktor kinerja adalah jarak antara lokasi nasabah ke kantor atau pos desa LKM (JARAK). Jauhnya jarak berpengaruh sangat signifikan terhadap penurunan jumlah penabung $\left(r_{s}=-0,4959, \alpha=0,000\right)$ dan jumlah peminjam $\left(r_{s}=0,4816, \alpha=0,000\right)$, serta peningkatan jumlah penunggak $\left(r_{s}=0,3981, \alpha=\right.$ $0,000)$ dan biaya per rupiah kredit $\left(r_{s}=0,2292, \alpha=0,019\right)$ juga berpengaruh sangat signifikan dalam penurunan laba per rupiah $\operatorname{kredit}\left(r_{s}=0,3406, \alpha=0,000\right)$.

2. Faktor lain yang cukup berpengaruh kepada faktor kinerja adalah lamanya waktu pemrosesan kredit (SELANG). Lamanya waktu pemrosesan kredit berpengaruh menurunkan jumlah peminjam cukup signifikan $\left(r_{s}=0,1325, \alpha=0,178\right)$, menurunkan laba per rupiah kredit secara sangat signifikan $\left(r_{s}=0,2864, \alpha=0,003\right)$, meningkatkan biaya per rupiah kredit secaratidak signifikan $\left(r_{s}=0,1183, \alpha=0,229\right.$, meningkatkan jumlah penunggak walaupun tidak signifikan $\left(r_{s}=0,0706, \alpha=0,474\right)$.

3. Suku bunga pinjaman berpengaruh sangat signifikan terhadap jumlah peminjam $\left(r_{s}=\right.$ $0,2674, \alpha=0,006)$, berpengaruh cukup signifikan terhadap jumlah penunggak $\left(r_{s}=0,2073\right.$, $\alpha=0,109)$ dan berpengaruh tidak signifikan terhadap laba per rupiah kredit $\left(r_{s}=0,0276\right.$, $\alpha=0,780$ ), berarti bahwa suku bunga pinjaman sudah ada di batas atas, apabila dinaikkan akan menurunkan jumlah peminjam dan mengakibatkan meningkatnya jumlah penunggak, mengingat banyaknya kredit murah serta persaingan berat dari BRI Unit 
dan BPR yang memperoleh fasilitas kredit dari pemerintah. Akan tetapi dilihat dari kuat dan signifikannya korelasi, jarak mempunyai dampak yang lebih kuat terhadap berkurangnya jumlah peminjam dan bertambahnya jumlah penunggak dibandingkan suku bunga pinjaman. Hal sederhana ini kiranya dapat dimaklumi, karena jauhnya jarak lokasi LKM akan menyebabkan nasabah malas untuk berhubungan karena besarnya "biaya transaksi" yang harus ditanggungnya, yaitu biaya angkutan dan hilangnya waktu meninggalkan pekerjaan.

Tabel 2

Korel asi antara Penghasilan Rata-rata N asabah dengan Faktor Kinerja untuk Seluruh LKM dan Per Jenis LKM

\begin{tabular}{llllll}
\hline & AKPEN & AKPEM & PERPUNG & BIRP & LARP \\
\hline LKM (105) & $-.0539(.585)$ & $.0237(.610)$ & $.0063(.949)$ & $.3670(.000)$ & $-.1131(.251)$ \\
KSM (28) & $-.1466(.456)$ & $-.0309(.876)$ & $-.1131(.567)$ & $.1281(.516)$ & $-.1840(.349)$ \\
BKD (61) & $.1245(.339)$ & $-.0025(.985)$ & $.0601(.645)$ & $.3194(.012)$ & $.0565(.668)$ \\
BKK (16) & $.5500(.027)$ & $.3412(.196)$ & $-.2912(.274)$ & $.2784(.297)$ & $\rightarrow 0$ \\
\hline
\end{tabular}

4. Dari analisis mengenai pengaruh penghasilan nasabah dan jumlah tabungan rata-rata terhadap kinerja, dapat diungkapkan beberapa temuan yang menarik.

(a) Dilihat LKM sebagai keseluruhan, pengaruh penghasilan nasabah terhadap kinerja tidak begitu signifikan. A kan tetapi apabila dianalisis per jenis LKM , terlihat bahwa penghasilan nasabah paling berpengaruh terhadap kinerja BKK, terutama kepada jumlah penabung $\left(r_{s}=0,5500, \alpha=0,027\right)$, jumlah peminjam $\left(r_{s}=0,3412, \alpha=0,196\right)$, dan jumlah penunggak $\left(r_{s}=0,2912, \alpha=0,274\right)$, sedangkan pengaruhnya padaBKD kurang signifikan. Dari sini dapat disimpulkan bahwa pada BKK, nasabah yang penghasilannya relatif lebih tinggi mempunyai akses kepada pelayanan tabungan dan pinjaman yang lebih besar dibanding dengan nasabah yang 98.169 di tahun 1992 dan melonjak menjadi Rp 132.594 di tahun 1993 (DAI, 1993).

(b) Dilihat per segmen nasabah terdapat perbedaan perilaku apabila penghasilannya meningkat: nasabah BKD yang relatif kurang mampu lebih suka menabung dan tidak memi njam, nasabah BKK yang relatif lebih mampu meningkatkan tabungan tetapi terus memanfaatkan kredit, sama dengan perilaku pengusaha besar nasabah bank umum.

(c) Walaupun begitu terlihat masih adanya sifat jujur dan mandiri pada pengusaha mikro nasabah BKK dibanding pengusaha besar nasabah bank umum saat ini, yaitu apabila penghasilan pengusaha mikro nasabah BKK meningkat, mereka 
meningkatkan tabungan, terus memanfaatkan kredit dan tidak lupa melunasi tunggakannya, tetapi apabila pendapatan pengusaha konglomerat nasabah bank umum meningkat (dan pasti setiap tarikan napas menghasilkan uang), belumtentu mengurangi jumlah penunggak, karena sebagian dari mereka sengaja menunggak dan memacetkan kreditnya.

\section{Implikasi Kebijakan}

1. Mengingat jarak merupakan variabel yang paling mempengaruhi kinerja, LKM diharapkan membuka sebanyak mungkin pos pelayanan dan/ atau mengintensifkan kunjungan lapangan. Otoritas perbankan hendaknya tidak melarang pembukaan pos pelayanan ataupun memberi sanksi berupa penutupan pos pelayanan ("kantor di bawah kantor cabang") kepada LKM yang sudah menjadi BPR karena al asan tingkat kesehatan yang tidak baik, oleh karena

(a) kriteriaCAMEL tidak menampung aspirasi dan misi LKM (tersurat ataupun tersirat dalamUndang-undang) sebagai pelayan keuangan bagi masyarakat papan bawah,

(b) pelarangan pembukaan kantor di bawah kantor cabang kiranya dapat dihapuskan, karena pengertian "kantor di bawah kantor cabang" bagi LKM umumnya bukan merupakan gedung atau kantor seperti bank umum, tetapi mungkin hanya sekedar meja dan kursi tempat petugas lapangan menemui nasabahnya,

(c) pelarangan/ penutupan pos pelayanan justru akan lebih memperparah kinerja LKM, karena menghambat akses kepada masyarakat yang merupakan sumber dana dan penghasilannya.

2. Mengingat pula bahwa lamanya waktu pemrosesan kredit juga berpengaruh cukup kuat kepada kinerja, maka keputusan pemberian kredit kepada peminjam baru hendaknya dilakukan sesegera mungkin, sedangkan pemrosesan kredit ulangan hendaknya dapat diselesaikan pada hari yang sama.

3. Pengawas BPR hendaknya tidak melihat pemberian kredit dalam jumlah kecil-kecil pada LKM sebagai suatu hal yang "tidak efisien" atau "tidak maju”, karena hal itu justru sesuai dengan misi LKM membantu pengentasan kemiskinan. Mendorong LKM untuk memberikan kredit dalam jumlah yang semakin besar berarti menjauhkan LKM dari nasabahnyayang miskin, seperti terlihat pada gejala pemberian kredit BKK di atas.

4. BKD telah beroperasi selama satu abad dan BKK selama hampir tiga dasawarsa dengan pendekatan pasar yang telah membuat mereka lestari (sustainable) dan mandiri, keadaannya justru dibuat seperti "tel or di ujung tanduk" karena banyaknya programprogram kredit murah bersubsidi di perdesaan. A danya kredit dari pemerintah untuk BPR condong menguntungkan BPR Gaya Baru yang dimiliki para pemodal berdasi, 
memungkinkan merekamenurunkan sukubungakreditnya sehingga menambah pesaing bagi LKM. Di era reformasi ini pemerintah seyogianya lebih membina semangat keswadayaan masyarakat dan tidak menggunakan program-program kredit murah sebagai alat politik karena merusak moral itas masyarakat perdesaan yang masi jujur seperti terbukti dari perilakunyaterhadap LKM.

\section{D aftar Pustaka}

Badan Pembina BKK Propinsi JawaTengah, Perkembangan BKK dan BPR-BKK, 31 M aret 1994

Christen, Robert Peck, dkk, M aximizing the 0 utreach of $M$ icroenterpriseFinance, USAID Program and Operations Assessment Report No. 10, July 1995

Development A Iternatives, Inc., P roject Completion Report of Technical Support Provided to theF inancial Institutions D evelopment Project (U SA ID N 0. 497-0341) in Indonesia, May 1993

Dibyo Prabowo dan Sayogyo: The G reen R evolution: Sidoarjo, East Java, and Subang, W est Java, dalam Hansen, Gary E.(ed), A gricultural and Rural D evelopment in Indonesia, Westview Press, Boulder, 1981

Saidi, Zaim, Secangkir Kopi M ax H avelaar. LSM dan Kebangkitan M asyarakat, PT Gramedia Pustaka Utama-Yayasan Lembaga Konsumen Indonesia, Jakarta, 1995

Siegel, Sidney, Statistik Nonparametrik, terj. Zanzawi Suyuti \& Landung Simatupang,Gramedia,Jakarta,1997

Suharto, Pandu, Sejarah Pendirian Bank Perkreditan Rakyat, LPPI, Jakarta, 1988 